\title{
The rise of venture capital centres in China: a spatial and
}

\author{
network analysis
}

\begin{abstract}
:
Due to the importance of venture capital (VC) firms in spurring regional economic growth, the geography of VC firms and VC investments have attracted a lot of attention. However, the spatial patterns of cross-regional $\mathrm{VC}$ flows have rarely been explored, particularly in the context of emerging economies. Drawing on a unique dataset on VC firms and investments related to domestic initial public offerings (IPOs), this study combines location analysis with network analysis to investigate the spatial patterns of VC activities in China. The results confirm that Beijing, Shenzhen and Shanghai are the leading VC centres in the country. Although Yangtze Delta Area hosts the largest number of investments, Beijing and Shenzhen have a considerable advantage over Shanghai in terms of the number of VC firms, investments, and the number of domestic VC-backed IPOs. Beijing and Shenzhen also appear more central than Shanghai in China's VC networks, with Beijing-Shenzhen representing the most important city-dyad in terms of $\mathrm{VC}$ investment flows. The article explains how the dynamics of the $\mathrm{VC}$ centres is embedded in China's institutional and cultural context, critical to understanding the evolution and geography of China's VC industry.
\end{abstract}

Key words: Venture capital, Initial Public Offering, Institutional context, Beijing, Shenzhen, Shanghai

\section{Introduction}

Due to the importance of venture capital (VC) firms in spurring high-tech industries and regional economic growth, the geography of $\mathrm{VC}$ firms and $\mathrm{VC}$ investments have attracted a lot of research (Florida and Smith 1993, Florida and Kenney 1988, Mason and Harrison 2002, Schwartz and Bar-El 2007, Zhang 2011, Martin et al. 2005, Martin, Sunley and Turner 2002, Mason and Pierrakis 2013, Fritsch and Schilder 2012, Sorenson and Stuart 2001). It has been documented that VC activities are highly agglomerated in selected regions of a country. For example, VC firms and companies backed by VC firms in the US are extremely concentrated in San Jose-San Francisco, New York and Boston (Lerner 2010, Florida and Smith 1993, Sorenson and Stuart 2001). Similarly, VC firms and investments are concentrated in the Greater London and South East of the UK (Martin et al. 2005, Mason and Harrison 2002). A study on China finds that VC activities are highly concentrated in Beijing, Shanghai and Shenzhen (Zhang 2011).

Existing studies identify the national VC centres, in which $\mathrm{VC}$ firms and portfolio companies they invest in are geographically co-located. The co-location of VC firms and the invested companies has largely been explained with the benefits of geographical proximity helping to reduce information asymmetry and transaction costs (Zook 2002, Florida and Smith 1993). For targets 
further away, VC firms often overcome the friction of distance by co-operating with VC firms located close to the target through a process called syndication (Fritsch and Schilder 2012, Sorenson and Stuart 2001). Despite the proximity preference, the cross-regional investments still account for a large proportion of all VC investments. For instance, there were substantial VC flows from New York and Chicago to high-technology regions in other parts of the country (Florida and Smith 1993), and as much as $57 \%$ of all VC investments in the US represented cross-regional flows (Chen et al. 2010).

Beyond works on syndication, few studies consider cross-regional flows of information and capital involved in venture capital deals. While the local bias and proximity preference of VC firms have been well understood (Chen et al. 2010), the patterns of cross-regional VC flows have rarely been studied, though they are crucial to understanding VC activities. For example, it is important to know how urban and regional centres of $\mathrm{VC}$ are connected with other regions and how they interact with each other. One key concern of existing studies on the geography of VC investments has been the regional disparity in VC activities and the related policy interventions (Martin et al. 2002, Mason and Pierrakis 2013). Understanding the spatial behavior of VC firms in cross-regional investments is key to designing such interventions.

Following studies on city networks (Taylor et al. 2014b, Derudder et al. 2010, Taylor and Aranya 2008, Taylor 2005, Derudder et al. 2003, Taylor, Catalano and Walker 2002), the methodology of urban network analysis could be applied to map and analyze the cross-regional behavior of VC firms as inter-city investments account for a large proportion of $\mathrm{VC}$ activities. As pointed out by Taylor et al. (2014b), strategic places can be defined through strategic networks. Thus, the importance of a $\mathrm{VC}$ centre is not solely determined by the $\mathrm{VC}$ activities occurring within the city, but is also determined by how the city is connected with other cities with regard to VC flows. In addition, city-dyad analysis (Taylor et al. 2014a) could also be used to enhance our understanding of the VC behaviors across cities and regions.

The development of VC industry is embedded in the institutional and cultural context of an economy. Previous studies on China have emphasized the unique institutional and cultural factors that have influenced the development of VC industries (Zhang 2011, Batjargal 2007, Ahlstrom, Bruton and Yeh 2007, Kambil, Long and Kwan 2006, White, Gao and Zhang 2005). For instance, it was pointed out that geographical proximity in China might be more important in VC practices as the achievement of a $\mathrm{VC}$ investment needs frequent personal interactions to build up and cultivate social capital or guanxi (Zhang 2011, Batjargal 2007, Kambil et al. 2006). However, how the institutional and cultural context in China have affected the spatial pattern and networks of VC flows in China remains understudied. Given that state still plays a key role in China's economy, this study seeks to provide institutional explanations on the geography of VC activities, and in particular, the rise and dynamics of Beijing, Shenzhen and Shanghai as key centres of China's VC industry. Does China display similar patterns of concentration and cross-regional cooperation in VC activities as the US or UK do? Do particular institutional features explain the distribution of VC activities in China? Drawing on a unique dataset on China's VC firms and their portfolio companies listed on domestic stock exchanges, this study seeks to answer the above questions by combining the location analysis with network analysis. The rest of the paper is organized as 
follows. The second section briefly introduces the recent boom of VC industry in China, driven primarily by the establishments of two new stock market platforms. The third section describes the data and methodology followed by a section portraying the geography of VC firms and VC investments. The fifth section maps the networks of $\mathrm{VC}$ flows across regions. The sixth section provides an institutional explanation of the dynamics of leading $\mathrm{VC}$ centres. The last section concludes the paper.

\section{Evolution of VC firms in China's institutional context}

As an emerging economy, China has experienced a dramatic growth in VC industry in the last decade becoming the second largest VC market across the world (Zhang 2011). However, domestic VC firms were not quite successful in early years due to the lack of divestment channels. Domestic VC firms started to grow quickly after the establishment of the Small and Medium-Sized Enterprise Board (SMEB) in 2004. The booming of domestic VC firms and the geography of the industry have been shaped by a unique institutional context.

\section{Slow development of domestic VC firms in early years}

China started to develop its VC industry in the 1980s, though at a very slow pace (Ahlstrom et al. 2007). Not surprisingly, governments were highly involved in setting up VC firms. For instance, the National Research Centre of Science and Technology for Development was established in 1984 aimed at developing high-tech industries (White et al., 2005). More venture capital firms backed by state and local government were set up in the 1990s, most of them in national high-tech industry parks across the country (Ahlstrom et al. 2007). However, the development of domestic VC was stifled due to the lack of divestment opportunities, with no Nasdaq-like segment on the Chinese stock market (White et al. 2005).

In contrast to domestic VC firms, foreign VC firms in China experienced rapid growth in the late 1990s and early 2000s, highly related to the strong stock market performance in the US (Pukthuanthong and Walker 2007). Many foreign VC firms that invested in Internet-related portfolio companies successfully exited via IPOs on overseas stock exchanges (Pan and Brooker 2014, Zhang 2008, Batjargal 2007, Zhang 2013). During that period, foreign VC firms found that "big deals with big payoffs are easy to find" (Bloomberg, 2004) ${ }^{1}$. However, domestic VC firms had no access to IPO channels on either foreign or domestic stock exchanges (White et al, 2005; Zeng, 2004). Many successful listings on overseas stock exchanges motivated China's policy makers to launch its own Nasdaq-like stock market segment (Pan and Brooker 2014). During this period, active foreign $\mathrm{VC}$ activities were extremely concentrated in several metropolitan areas in east China (Pukthuanthong and Walker 2007).

\section{Boom of domestic VC firms after the launch of the new markets}

China planned to establish Nasdaq-like stock markets from the late 1990s. It was expected that the

\footnotetext{
1 http://www.bloomberg.com/bw/stories/2004-03-21/venture-capitalists-catch-china-fever
} 
second board would be set up in Shenzhen in $2000^{2}$ (China Daily, 2004). However, the bust of the dot.com bubble in the US's capital market delayed this development. In 2004, the SMEB was finally launched, providing an opportunity for domestic VC firms to divest in their portfolio firms through an IPO. The establishment of Chinext in Shenzhen in 2009 was another huge incentive for domestic VC industry. Prior to the launch of the SMEB, the central government used China's stock market to help capitalize and improve transparency of the state-owned firms (Green 2004, Walter and Howie 2003). Most firms that conducted IPOs on domestic stock exchanges in this period were state-owned and VC firms rarely had a chance to invest in them. Though the SMEB and Chinext have strict financial requirements for IPO candidates, the launch of the two new boards have become a fundamental driver for the booming domestic VC industry. From then on, domestic IPO has become a major way for domestic VC firms to exit from their investments in China.

Not surprisingly, state-owned VC firms have become dominant in the rapid growth of domestic VC industry since about 2004. In China, the government is highly involved in the economic governance (Naughton 2011) and plays a significant role in financing ${ }^{3}$ (China Daily, 2011). In particular, China has a tradition in setting up government-financed VC firms to support start-ups (White et al. 2005). Domestic VC firms were largely controlled by government bodies at central, regional and local levels, large SOEs or state-owned universities (White et al, 2005). In the meantime, privately-owned VC firms were also emerging, including spin-offs and spin-outs from established VC firms, stock-exchange listed firms and those set up by former government officials.

\section{IPO regulation system and the role of VC firms in the IPO process}

Existing studies demonstrate that VC firms may play a critical role in the IPO process (Gompers 1996, Gulati and Higgins 2003, Hochberg, Ljungqvist and Lu 2007, Barry et al. 1990). Well-connected VC firms usually outperform others in terms of VC exits through IPO (Hochberg et al. 2007, Gulati and Higgins 2003). In China, social capital or guanxi have been considered as extremely important in VC activities (Batjargal 2007, Zhang 2011, Kambil et al. 2006). What has not been considered however, is the mutual relationship between the IPO regulation and the strategies of VC firms.

Before discussing the impacts of institutional factors on VC firm strategies, it is necessary to know more about the IPO regulation system. Table 1 summarizes major procedures firms must go through to conduct an IPO on a domestic stock exchange. Chinese Securities Regulatory Commission (CSRC), not the stock exchanges, is the main organization reviewing IPO applications and approving them. In addition, other local and central government agencies are engaged in the process. All in all, domestic IPOs are highly regulated and require many procedural steps controlled by governments of different levels.

The application process is long and unpredictable. Moreover, the CSRC frequently suspended new

2 http://www.china.org.cn/english/BAT/98542.htm

3 http://www.chinadaily.com.cn/kindle/2011-07/15/content_12911473.htm 
IPOs without any notice. The longest suspension was over 1 year. Thus, many firms turned to overseas stock exchanges (Pan and Brooker 2014, Gucbilmez 2014). In addition, the financial requirements of domestic IPOs have been stricter than those in advanced economies. In particular, the revenue and profit of firms are key indicators for the success of domestic IPO application, making it difficult for young firms to get an approval.

Table 1 Stages of an IPO process in China

\begin{tabular}{|l|l|l|}
\hline Procedure & Government agencies involved & Duration \\
\hline $\begin{array}{l}\text { Restructuring the } \\
\text { enterprise and setting up a } \\
\text { share holding company }\end{array}$ & Agencies of local government & Conditional \\
\hline $\begin{array}{l}\text { Due diligence, } \\
\text { investigation and guidance }\end{array}$ & $\begin{array}{l}\text { Local Securities Regulation } \\
\text { Bureau }\end{array}$ & Conditional \\
\hline $\begin{array}{l}\text { Preparing an application to } \\
\text { CSRC }\end{array}$ & CSRC & $2-3$ months \\
\hline $\begin{array}{l}\text { Review of the application } \\
\text { by CSRC and other } \\
\text { agencies }\end{array}$ & $\begin{array}{l}\text { CSRC, provincial government, } \\
\text { National Development and } \\
\text { Reform Commission (NDRC) }\end{array}$ & $3-9$ months \\
\hline $\begin{array}{l}\text { Road show, pricing and } \\
\text { listing }\end{array}$ & The stock exchange & $3-4$ weeks \\
\hline
\end{tabular}

Source: Compiled from websites of Shanghai Stock Exchange

(http://www.sse.com.cn/marketservices/listing/tobelisted/listcondition/\#2) and Shenzhen Stock Exchange (http://www.szse.cn/main/nssqyfwzq/fxssxz/qygzsslc/).

The unique institutional context may have a fundamental influence on the strategies of VC firms. It is a challenge for VC-backed firms to obtain a public listing on Chinese markets due to the uncertainties involved in the IPO process (Humphery-Jenner and Suchard 2013). Given that VC firms are highly involved in the concerted efforts to get a firm listed, the ability of a VC firm to make it happen is considered the key aspect of its competitiveness (Kambil et al. 2006). Political ties and guanxi are extremely important in IPO applications (Gucbilmez 2014, Jiang et al. 2014, Zhang 2014, Tan, Huang and Lu 2013). When VC firms involved in the process are politically connected or have more connections with capital market intermediaries, the portfolio firm is more likely to get publicly listed, and these VCs can speed up a portfolio firm's exit through IPOs in China (Wang, Anderson and Chi 2013). Thus, VC firms with better access to key resources for IPO approval are more likely to get their invested firm listed quickly and therefore are more attractive to potential portfolio companies.

On the other hand, the supply of new IPOs in China has been limited, which has resulted in the high valuation of new stocks. Any firm that has the potential to be publicly listed represents a great opportunity for VC firms (Lu, Tan and Huang 2013). The competition between VC firms thus becomes extremely fierce. This results in 'capital chasing projects', which means that potential portfolio companies could choose among VC firms (Zhang and Li 2015). The VC firms

4 Firms to be listed on Chinext do not have to get approval from NDRC. 
with better access to key resources to get an IPO approval, are more attractive portfolio companies. For instance, a recently disclosed report by Chinese media shows that a VC firm located in Beijing invested in seven firms in a "precise way" before they went public and had made extraordinary revenues after the IPOs ${ }^{5}$. The VC firm has a strong connection with a high-level government official accused of corruption.

The discussion on the significance of the domestic IPO process to the development of the VC industry in China raises an important question. How does the geography of $\mathrm{VC}$ activities relate to the geography of domestic IPOs? Given that VC firms that have better access to key resources for domestic IPO might be more active and successful, the geography of the key resources to IPO process should be critical to understanding the geography and network of VC flows. In particular regions with privileged access to IPOs should stand out in terms of their VC industry. The following sections will address these questions.

\section{Data and methodology}

In this study $\mathrm{VC}$ firms are broadly defined as institutions that make equity investment in fast growth ventures including both early stage firms and late stage firms that are not publicly listed. The latter is usually referred to as a private equity (PE) fund. In China's context, the terms VC and PE are often used interchangeably (Ahlstrom et al. 2007).

Data for this research comes from Zero2IPO database ${ }^{6}$, which collects detailed information on all publicly listed firms and the VC firms involved in their development prior to the IPO. Given the strict financial requirements and unique IPO regulation system, most listed firms are from manufacturing industry and relatively large in size. Despite the differences of institutional settings of various cities in supporting different industries (Segal and Thun 2001), VC activities related to domestic IPOs in China are not focused on any specific sector and therefore the industrial advantage of a city will not necessarily bring about active VC activities. Most firms are listed on the SMEB and Chinext, with only 56 out of 516 firms listed on the Shanghai Stock Exchange (SSE). In addition, very few VC-backed listed firms are state-owned.

The dataset covers all firms that had an IPO before the end of 2013. Due to the IPO suspension, there were no new domestic IPOs in the year of 2013. Thus, the latest listing included in the database occurred at the end of 2012. The dataset allows us to find the locational information for all VC firms involved in portfolio firms that had an IPO on domestic stock exchanges in Shanghai and Shenzhen. The VC firms and portfolio firms are aggregated and analyzed at city level. One $\mathrm{VC}$ flow is defined as a connection between a VC firm located in city A investing in a firm located in city B. ArcGis is used to map the networks formed by VC investment flows across cities in

\footnotetext{
5 http://www.chinadaily.com.cn/hqcj/zgjj/2014-12-24/content_12936164.html

${ }^{6}$ Zero2IPO Group, founded in 1999, is a leading integrated service provider and investment institution in China's private equity industry. Zero2IPO has one of the most recognized dataset of VC and PE investment deal information in China.
} 
China.

We focus on the locational information of $\mathrm{VC}$ firms rather than VC funds. One VC firm can have many funds with different portfolio companies and geographical structures. Funds managed by a single VC firm might be registered in different cities. However, provided that the VC firm is the commanding centre in final investment decisions and where the key resources related to IPO application are located, it is more reasonable to explore the geography and networks of VC flows based on the location of VC firms rather than VC funds.

\section{Geography of VC firms and investments}

In our dataset, the first VC-backed IPO in Mainland China was conducted in 1994, when VC industry was still in its early stage of development and VC investments were rare. VC firms became actively involved in investing in firms with potential to be publicly listed on domestic stock exchanges in China around 2004, when the SMEB was established. The launch of Chinext in 2009 was another incentive for VC firms to expand. Thus, most publicly listed firms backed by VC firms had their IPOs after 2004.

As it may take several years for a company to get publicly listed after they were invested by VC firms, more VC investments could be disclosed when more IPOs are conducted. Regardless of this limitation of data, Figure 1 shows a coincidence of $\mathrm{VC}$ investments that finally exited via domestic IPOs and the number of new IPOs each year in China. As it is common that several VC firms co-invest in one portfolio company, there are more VC investments than VC-backed IPOs.

As shown in Figure 1, the VC investments increased in 2006 and reached the first peak in 2007. After one year's stagnation, they started to grow again from 2009 at an unprecedented pace. Meanwhile, the number of VC-backed IPOs grew from 2005 and peaked in 2011. By the end of 2013, there were 516 publicly listed firms that were backed by VC firms.

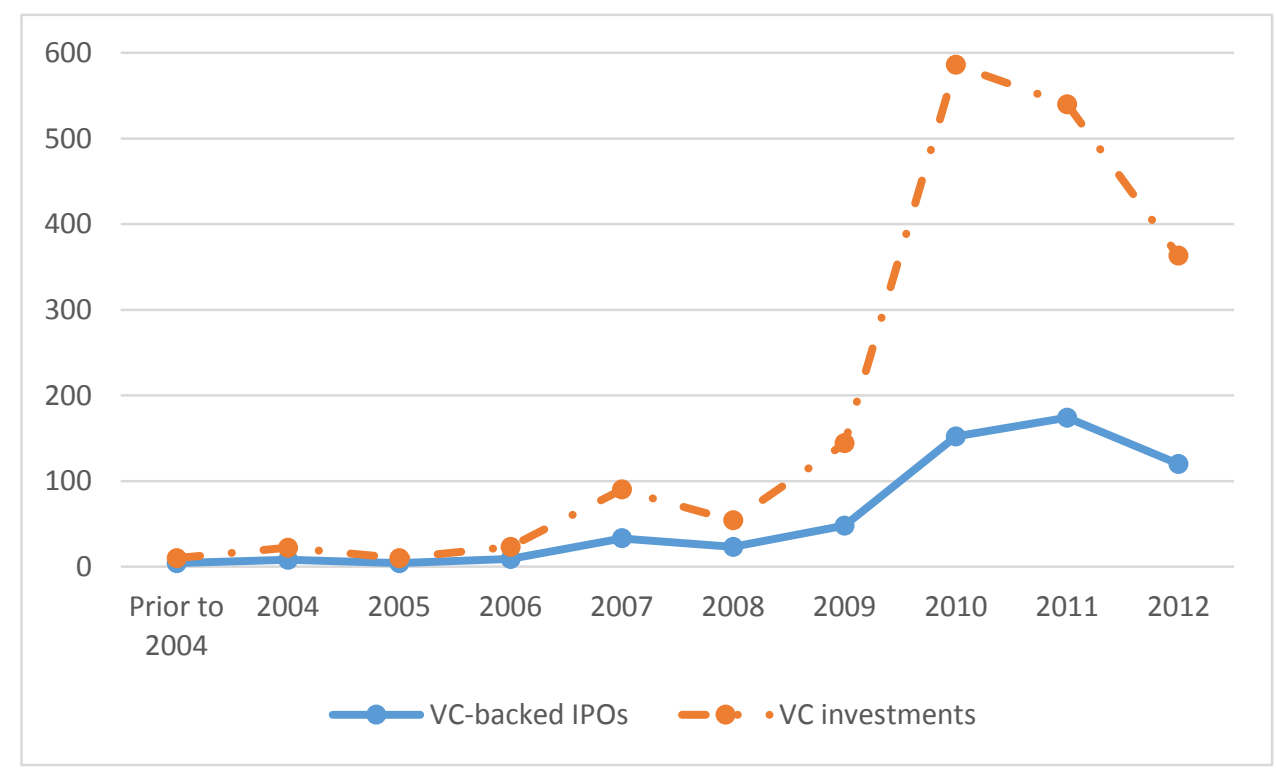


Figure 1 Number of VC-backed IPOs and VC investments from 1994-2012

\section{The Spatial pattern of VC activities across the country}

Not surprisingly, there is a significant regional disparity in the distribution of IPO firms that received VC investments, despite their presence across 30 provincial regions (all except Tibet). VC-backed firms are highly concentrated in coastal regions, while less presence in the central and western part of the country (See Figure 2).

Beijing leads with 63 VC-backed listing firms followed by Shenzhen with 60 firms. Suzhou ranks third with 27 firms, lagging behind Beijing and Shenzhen but ahead of Shanghai with only 24 VC-backed listings. There are only 9 cities with over $10 \mathrm{VC}$-backed listing firms. Most cities with a significant number of VC-backed listing firms are located in coastal regions, and those inland are mostly provincial capital cities, such as Chengdu, Changsha and Wuhan.

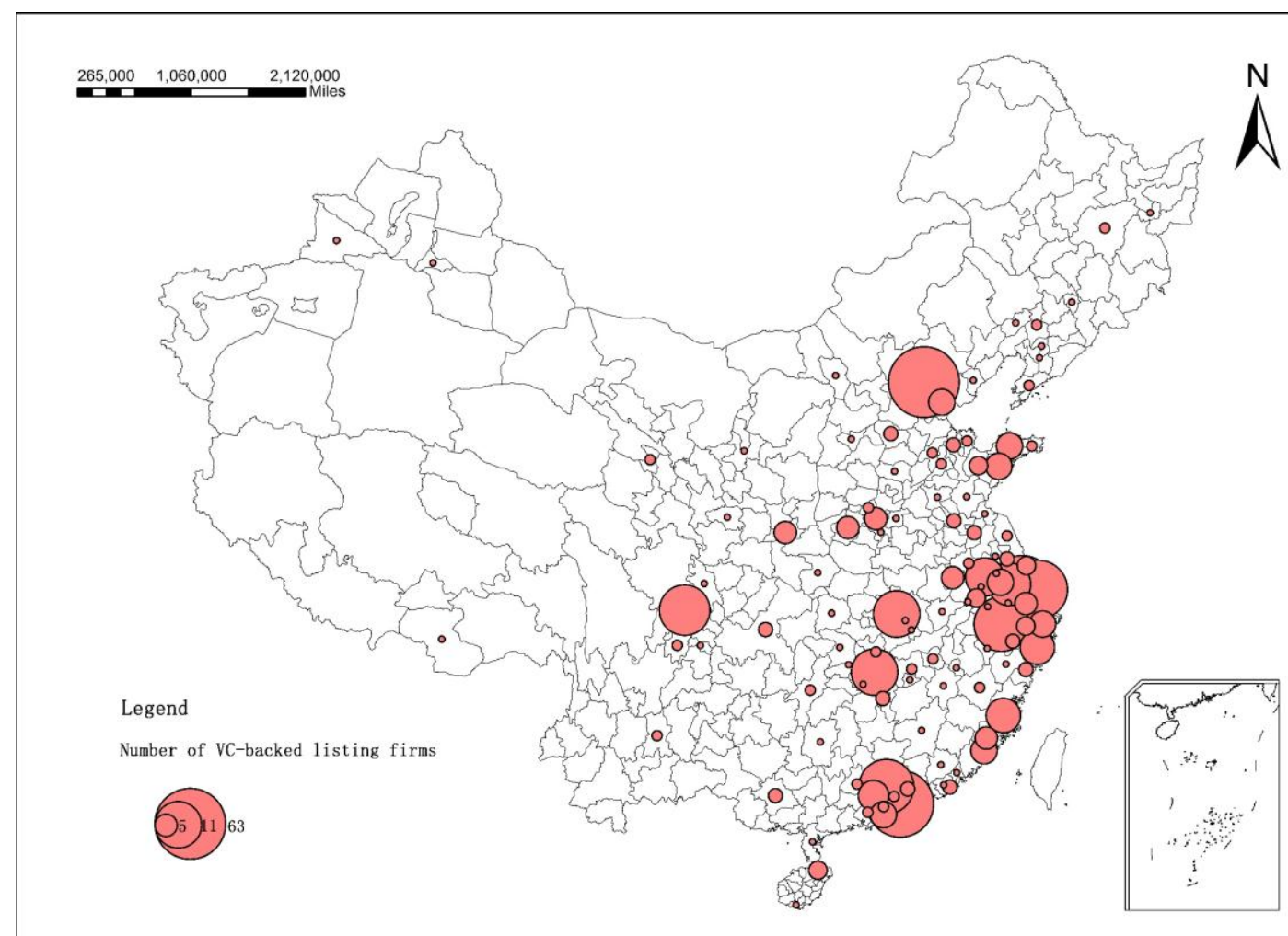

Figure 2 Distribution of VC-backed listing firms in China

There are $434 \mathrm{VC}$ firms in total involved in 1148 investment deals related to the publicly listed firms. Compared to the geography of portfolio companies, VC firms are more concentrated in fewer cities. Only 41 cities have VC firms' presence. The VC firms are extremely concentrated in the coastal area (Figure 3). Beijing (107), Shanghai (94) and Shenzhen (63) are the top three cities with the largest number of $\mathrm{VC}$ firms, together accounting for $61 \%$ of the national total investment 
deals made by VC firms are mostly from Shenzhen (299), Beijing (281) and Shanghai (191), the three accounting for about $67 \%$ of the total number of investment deals and about $70.1 \%$ of their value.

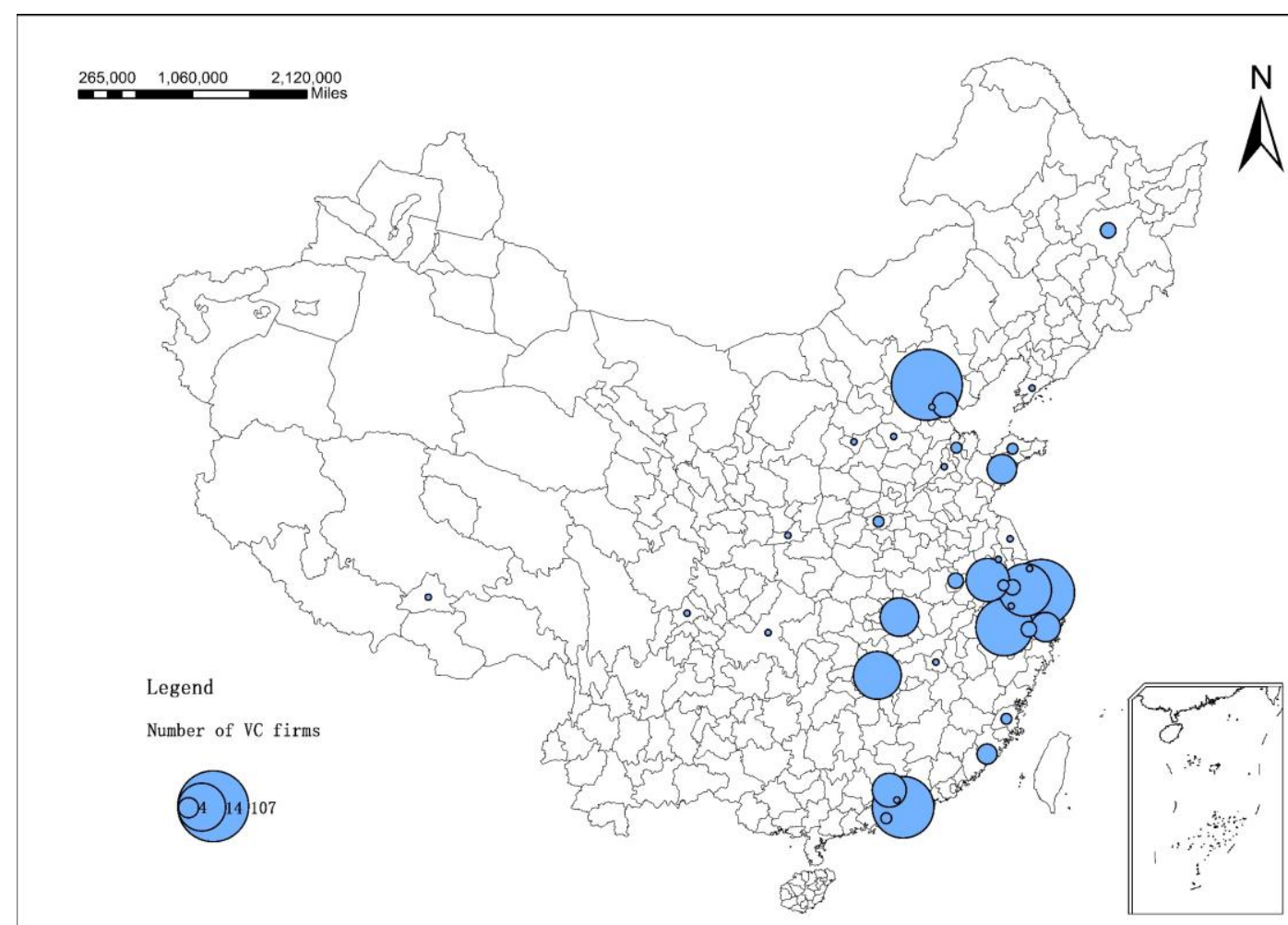

Figure 3 Distribution of VC firms in China

\section{Dominance of Beijing, Shenzhen and Shanghai in the geography of VC in China}

Beijing, Shanghai and Shenzhen are the dominant VC centres of China. The three cities have accounted for approximately $28.5 \%$ of all VC-backed listing firms, $60.8 \%$ of all VC firms backing IPOs, and $67 \%$ of the total number of VC investments made by these firms. This implies that VC firms located in these cities are larger and/or make more investments than those located in the rest of the country.

Beijing hosts the largest number of VC-backed firms and VC firms. Although Shenzhen has fewer VC firms than Beijing and Shanghai, the number of investment deals made by VC firms from Shenzhen is the largest, which indicates that VC firms in Shenzhen are more active. The results also show that Shanghai appears less influential than Beijing and Shenzhen as a VC centre. 


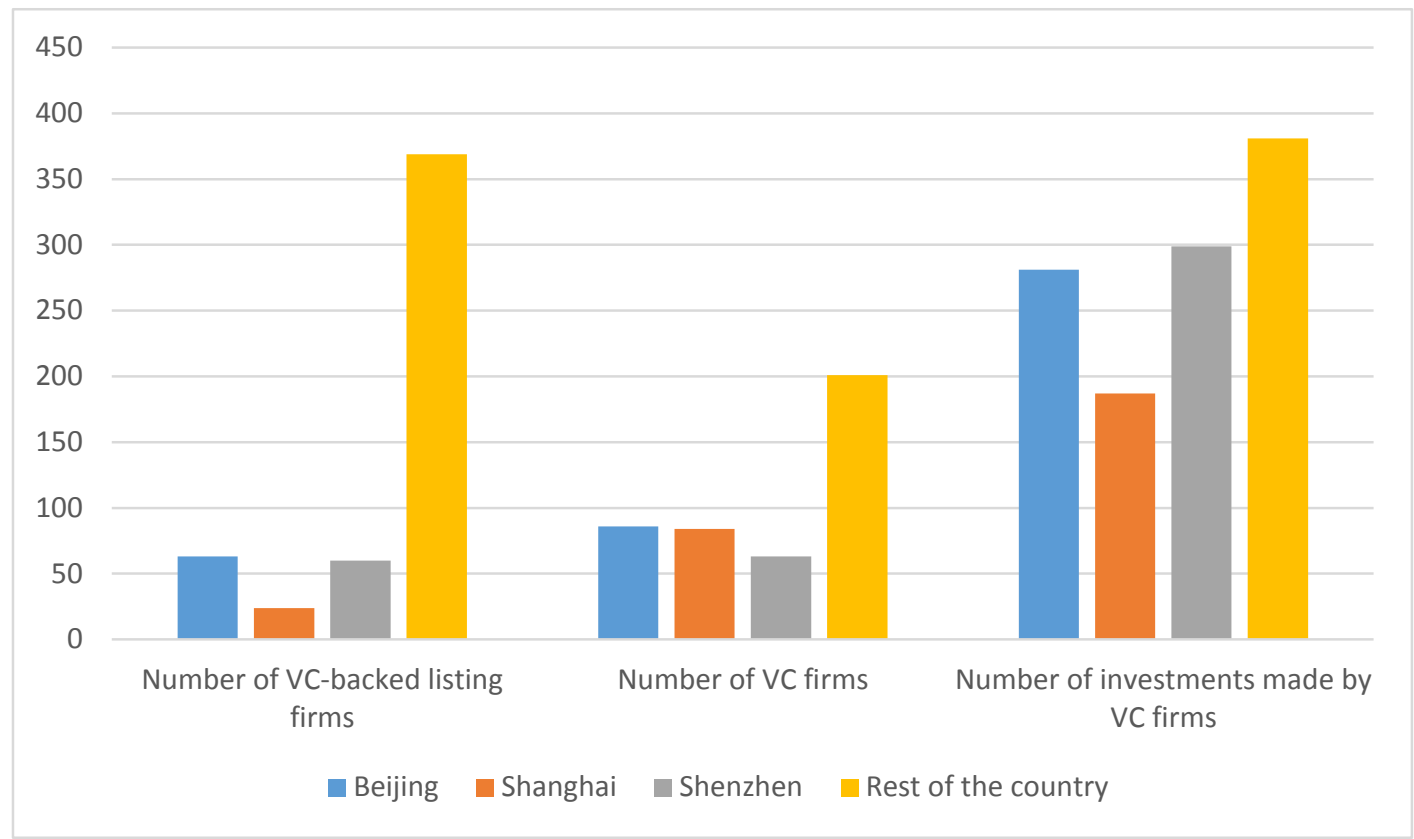

Figure 4 VC activities in Beijing, Shanghai, Shenzhen and the rest of the country

As shown in Figure 2 and Figure 3, the concentration of VC activity in major cities is accompanied by strong patterns of regional concentration. There are three regional centres of $\mathrm{VC}$ activities including the Yangtze Delta Area, Jing-Jin-Ji Area and Pearl Delta Area in China ${ }^{7}$. Table 2 summarizes VC activities in these three regions. The Yangtze Delta Area is the largest regional VC centre with the leading city Shanghai surrounded by Suzhou, Hangzhou, Wuxi, Nanjing and others. In the Pearl Delta Area, Shenzhen is the leading city, followed by Guangzhou and a couple of other cities. Overall, there are clusters of cities with relatively strong presences of VC activities in the Yangtze Delta Area and Pearl Delta Area. While Beijing is dominant in Jing-Jin-Ji Area, Tianjin is less influential than may be expected and other cities in this area do not host significant in $\mathrm{VC}$ activities.

Table 2 Three leading regional VC centres in China

\begin{tabular}{|c|c|c|c|}
\hline & $\begin{array}{c}\text { Number of } \\
\text { VC-backed listing } \\
\text { firms }\end{array}$ & Number of VC firms & $\begin{array}{c}\text { Number of } \\
\text { investments made by } \\
\text { VC firms }\end{array}$ \\
\hline Yangtze Delta Area & 174 & 121 & 298 \\
\hline Jing-Jin-Ji Area & 114 & 74 & 176 \\
\hline Pearl Delta Area & 76 & 102 & 241 \\
\hline
\end{tabular}

\footnotetext{
7 Note: The Yangtze Delta Area includes Shanghai; Nanjing, Suzhou, Wuxi, Changzhou, Zhenjiang, Yangzhou, Taizhou, Nantong from Jiangsu province; and Hangzhou, Ningbo, Huzhou, Jiaxing, Shaoxing, Zhoushan and Taizhou from Zhejiang province. The Jing-Jin-Ji Area includes Beijing; Tianjin; Baoding, Zhangjiakou, Qinhuangdao, Tangshan, Shijiazhuang, Langfang, Xingtai, Handan, Hengshui, Cangzhou, Chengde from Hebei province. The Pearl Delta includes Guangzhou, Shenzhen, Foshan, Dongguan, Zhongshan, Zhuhai, Jiangmen, Zhaoqing and Huizhou from Guangdong province.
} 


\section{Mapping cross-regional VC flows}

Given that the VC investments represent the flows of capital and information, the importance of cities in the VC industry is not solely defined by the number of investment deals made in or by VC firms from them, but is also affected by the position of those cities in the networks of $\mathrm{VC}$ flows, which will be analysed in more detail in this section.

\section{Overall networks of $\mathrm{VC}$ flows}

Figure 5 shows the overall network of VC flows within China. In general, there is a significant regional disparity as cities in eastern part of China are better connected than those in the west, central and northeast parts of China. Several nodes within the network are influential. In particular, Beijing, Shenzhen and Shanghai stand out as the most connected cities, having 211, 213 and 171 investment linkages with 71, 66 and 55 cities, respectively. Out of all 516 VC-backed listing firms, 406 are connected to a VC firm from one of the three cities. Other important nodes are Hangzhou, Suzhou, Guangzhou and Nanjing. The network map also shows clusters of cities with VC activities. Again, the most important cluster is located in the Yangtze River Delta Area, including Shanghai, Hangzhou, Nanjing, Suzhou, Wuxi, Ningbo and Taizhou.

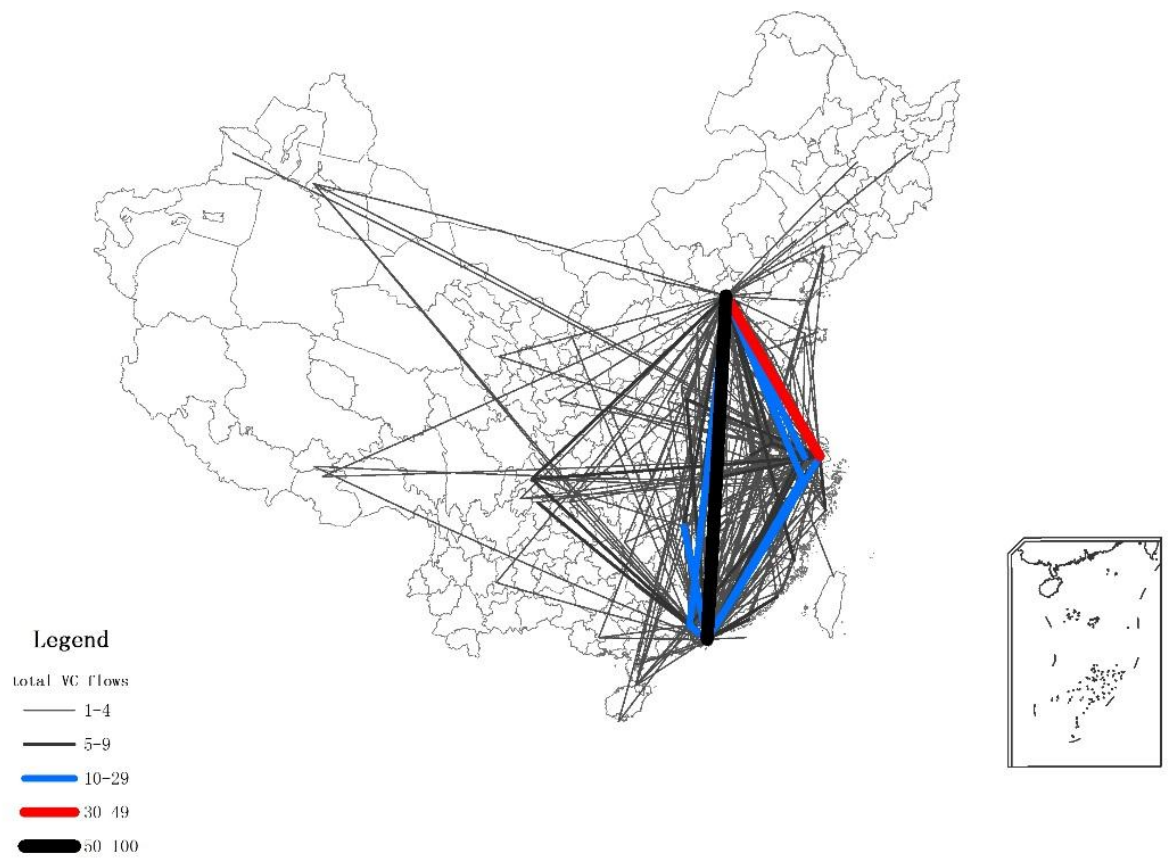

Figure 5 Overall networks of cross-city VC flows Note: The VC flows in the figure are bi-directional.

As a limited number of large cities are dominant within the $\mathrm{VC}$ network, flows between the top 10 cities can well represent the overall VC activities across China (Table 3). More than $84 \%$ of all VC 
firms are located in the top 10 cities. In addition, more than $93 \%$ of all $\mathrm{VC}$ investments were made by VC firms from one of the top 10 cities. Shenzhen, Beijing and Shanghai are the most important VC source cities, with Beijing and Shenzhen as the top 2 recipients of VC investments. Suzhou and Hangzhou ranked the third and fourth, followed by Shanghai as the fifth. More importantly, the top ten cities invest in each other intensively. The VC flows within the top 10 cities account for $50 \%$ of all VC investments of the country.

Table 3 VC sources and recipients between major VC centres in China

\begin{tabular}{lcccccccccccc}
\hline & BJ & SZ & SH & GZ & HZ & SZU & WH & CS & NJ & NB & $\begin{array}{c}\text { Other } \\
\text { origins }\end{array}$ & $\begin{array}{c}\text { In } \\
\text { total }\end{array}$ \\
\hline BJ & $\mathbf{7 0}$ & 34 & 25 & 1 & 6 & 2 & 0 & 0 & 2 & 0 & 11 & 151 \\
SZ & 24 & $\mathbf{8 6}$ & 13 & 4 & 6 & 0 & 0 & 1 & 1 & 0 & 8 & 143 \\
SH & 11 & 10 & $\mathbf{2 0}$ & 0 & 1 & 2 & 0 & 0 & 2 & 1 & 4 & 51 \\
GZ & 11 & 12 & 5 & $\mathbf{1 1}$ & 0 & 0 & 0 & 0 & 0 & 0 & 2 & 41 \\
HZ & 10 & 4 & 7 & 0 & $\mathbf{3 6}$ & 0 & 0 & 0 & 0 & 0 & 4 & 61 \\
SZU & 8 & 5 & 6 & 0 & 1 & $\mathbf{3 7}$ & 0 & 0 & 6 & 0 & 1 & 64 \\
WH & 8 & 3 & 7 & 0 & 0 & 0 & $\mathbf{1 0}$ & 0 & 0 & 0 & 1 & 29 \\
CS & 7 & 9 & 1 & 2 & 0 & 1 & 0 & $\mathbf{9}$ & 0 & 1 & 0 & 30 \\
NJ & 4 & 1 & 1 & 0 & 1 & 2 & 0 & 0 & $\mathbf{7}$ & 0 & 0 & 16 \\
NB & 4 & 3 & 3 & 0 & 2 & 0 & 0 & 0 & 0 & $\mathbf{4}$ & 1 & 17 \\
Other & 124 & 132 & 103 & 28 & 26 & 9 & 5 & 12 & 26 & 2 & $\mathbf{7 8}$ & 545 \\
destinations & & & & & & & & & & & & \\
Total & 281 & 299 & 191 & 46 & 79 & 53 & 15 & 22 & 44 & 8 & $\mathbf{1 1 0}$ & $\mathbf{1 1 4 8}$ \\
\hline
\end{tabular}

Note: BJ, Beijing; SZ, Shenzhen; SH, Shanghai; GZ, Guangzhou; HZ, Hangzhou; SZU, Suzhou; WH, Wuhan; CS, Changsha; NJ, Nanjing; NB, Ningbo.

\section{Recipients of investments from VC centres and the city-dyad of VC flows}

Table 4 lists the most invested cities by VC firms from Beijing, Shanghai and Shenzhen. The top 10 cities account for 58\%, 54\% and 68\% of all investments made by VC firms from Beijing, Shanghai and Shenzhen, respectively. Not surprisingly, there are a lot of within-city VC investments. VC firms from Beijing and Shenzhen invest in their home cities the most, with much more investments than other destinations. Shanghai is an exception as VC firms in Shanghai invest in Beijing more than they do locally.

Beijing and Shenzhen are also the most important recipients for VC investments (See Table 4), while Shanghai ranks $5^{\text {th }}$, lagging behind Suzhou and Hangzhou Other important recipient cities are mostly located in coastal areas, such as Guangzhou, Fuzhou, Wuxi, Taizhou, Wuxi, and Shantou. In addition, some cities located in the central part of China, including Changsha, Chengdu, Wuhan and Zhengzhou have received significant VC inflows from Beijing, Shenzhen and Shanghai. 
Table 4 The most invested cities by VC firms from Beijing, Shanghai and Shenzhen

\begin{tabular}{|l|l|l|l|}
\hline & Beijing & Shanghai & Shenzhen \\
\hline 1 & Beijing (70) & Beijing (25) & Shenzhen (86) \\
\hline 2 & Shenzhen (24) & Shanghai (20) & Beijing (34) \\
\hline 3 & Shanghai (11) & Shenzhen (13) & Guangzhou (12) \\
\hline 4 & Guangzhou (11) & Zhengzhou (7) & Shanghai (10) \\
\hline 5 & Hangzhou (10) & Wuhan (7) & Changsha (9) \\
\hline 6 & Wuhan (8) & Taizhou (7) & Zigong (5) \\
\hline 7 & Suzhou (8) & Hangzhou (7) & Zhengzhou (5) \\
\hline 8 & Changsha (7) & Chengdu (7) & Wuxi (5) \\
\hline 9 & Fuzhou (7) & Suzhou (6) & Suzhou (5) \\
\hline 10 & Chengdu (6) & Wuxi (5) & Shantou (5) \\
\hline & Rest of the country 119 & Rest of the country 87 & Rest of the country 95 \\
\hline
\end{tabular}

The geographical coverage of the outflows of VC investments from the three cities is shown in Figure 6. It appears that Beijing has a broader geographical coverage than Shenzhen and Shanghai, including presence in northern China. On the other hand, it seems that VC firms in Beijing do not frequently invest in neighboring cities. Conversely, Shanghai and Shenzhen are more connected with surrounding cities measured by VC linkages. For instance, Shenzhen invest a lot in Guangzhou, and Changsha. Shanghai invest a lot in Hangzhou, Suzhou, Wuxi and et al. The results also suggest that the regional economies are more integrated in Yangtze Delta Area and Pearl Delta Area than those in Beijing-Tianjin area.

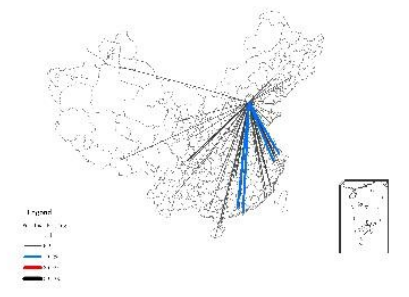

(a) Beijing

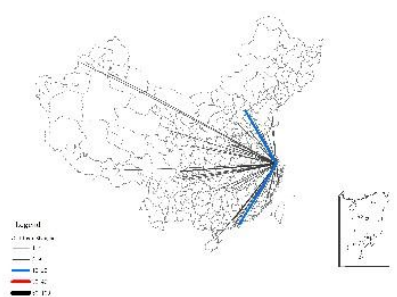

(b) Shanghai

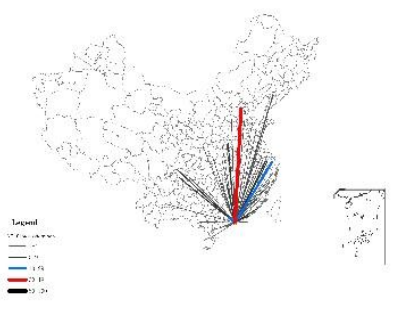

(c) Shenzhen

Figure 6 VC outflows from Beijing, Shenzhen and Shanghai

Table 5 lists the top 10 city-dyads in VC investment connections. Interestingly, all the city-dyads consist of at least one of the three dominant VC centres. Other cities that frequently appear in the city-dyads are Hangzhou, Guangzhou, Suzhou, Nanjing and Changsha. Among the top 10 city-dyads, Beijing and Shenzhen are both present in five of them, while Shanghai is only present in three. This again shows that Beijing and Shenzhen are better positioned than Shanghai in China's VC networks.

Beijing-Shenzhen is the most influential city-dyad in terms of VC flows, with 58 connections, much larger than that of Beijing-Shanghai and Shanghai-Shenzhen. There are $24 \mathrm{VC}$ investment 
flows from Beijing to Shenzhen, and Shenzhen is the most important destination of VC flows from Beijing. At the same time, there are $34 \mathrm{VC}$ investment flows from Shenzhen to Beijing, and Beijing is also the most important destination of VC flows from Shenzhen. Although both cities have plenty of capital and firms with potential to get publicly listed on domestic stock exchanges, there are many inter-city VC investments. Beijing and Shenzhen are the cities where organizations key to the IPO process are located and each city has different sorts of sources and advantages. Therefore, the two cities have potentials to collaborate with each other in VC activities related to domestic IPOs. In addition, Beijing-Shanghai and Shanghai-Shenzhen are the other two most important city-dyads with regards to VC flows.

As pointed out Beijing, Shanghai and Shenzhen are the leading cities of three regional VC centres. Beijing, Shanghai and Shenzhen have intensive connections with each other. In addition, each region's VC firms invest heavily within their own region. In particular, there are a lot of within-city investments. Surprisingly, however, Shanghai has relatively weak links with other Yangtze Delta Area cities. As Table 4 shows, Beijing has more VC connections with Hangzhou and Suzhou than Shanghai does. Shenzhen also has strong ties with Hangzhou and Suzhou, very close to Shanghai's performance. In addition, while Beijing and Shenzhen VC firms invest significantly in the Yangtze Delta Area, Shanghai VC firms do not seem to invest in a comparable way in the Jing-Jin-Ji and Pearl Delta Area. The results again indicate that Beijing and Shenzhen are better connected than Shanghai in VC networks.

Table 5 Top 10 city-dyads in VC investment flows

\begin{tabular}{|l|l|l|}
\hline No. & City-dyad & Amount \\
\hline 1 & Beijing-Shenzhen & 58 \\
\hline 2 & Beijing-Shanghai & 36 \\
\hline 3 & Shanghai-Shenzhen & 23 \\
\hline 4 & Beijing-Hangzhou & 16 \\
\hline 5 & Shenzhen-Guangzhou & 16 \\
\hline 6 & Shanghai-Hangzhou & 13 \\
\hline 7 & Beijing-Guangzhou & 12 \\
\hline 8 & Beijing-Suzhou & 10 \\
\hline 9 & Shenzhen-Changsha & 10 \\
\hline 10 & Shenzhen-Hangzhou & 10 \\
\hline
\end{tabular}

\section{The rise and dynamics of $\mathrm{VC}$ centres}

All results show that Beijing, Shenzhen and Shanghai are the dominant centres of China's VC industry and the leading cities within the three largest regional VC centres. Their dominance is also reflected by their well-connected positions within the network of VC flows. The intensive interactions between the three cities further make them the leading city-dyads in VC flows. However, it is surprising that Beijing and Shenzhen have significantly outperformed Shanghai as VC centres according to almost all indicators. Beijing-Shenzhen stands out the most important 
city-dyad in terms of VC flows, with large advantage over Beijing-Shanghai or Shenzhen-Shanghai. Given that the boom of VC activities was triggered by the launch of new boards on domestic stock exchanges, the rise and dynamics of the VC centres might also be embedded in China's unique institutional contexts.

\section{Dynamics of the VC centres over time}

As documented in prior research, Beijing, Shenzhen and Shanghai had emerged as China's leading VC centres since the late 1990s and foreign VC firms had been dominant (Zhang 2011). Not surprisingly, Beijing, Shanghai and Shenzhen are the most attractive cities for foreign VC firms and returnee entrepreneurs from advanced economies, particularly for people in Internet-related sector (Zhang 2008, Zhang 2013). The three cities are home to many high-tech firms that are listed on Nasdaq and NYSE (Pan and Brooker 2014) and were thus well-placed to benefit from the boom of foreign VC firms and entrepreneurs since the late 1990s.

However, the driving forces of the rise of Beijing, Shenzhen and Shanghai as VC centres in the new era might be different from those in early years. Our dataset of the $\mathrm{VC}$ activities related to domestic IPOs has enabled us to trace the role of Beijing, Shanghai and Shenzhen in China's VC market in the new era. As shown in Figure $7 \& 8$, Beijing, Shenzhen and Shanghai have become dominant in China's VC market in terms of VC-backed new listings and VC investments related to domestic IPOs since the launch of the SMEB in 2004. It shows that there was a tremendous spread of VC activities across the country around 2010, and it has been the result of the launch of the Chinext in 2009. However, Beijing, Shenzhen and Shanghai seemed to have regained their dominance in 2012. The percentage of VC-backed listing firms in the three cities dropped from $33.3 \%$ in 2009 to $23.2 \%$ in 2011 and rose to $30.4 \%$ in 2012 (See Figure 7). In addition, VC firms involved in investing in pre-IPO firms were more concentrated in the three cities. The percentage of investment made by VC firms located in Beijing, Shanghai and Shenzhen has grown from 50\% in 2010 to $74.9 \%$ in 2012 (See Figure 8).

Another important factor is that Beijing and Shenzhen have been ahead of Shanghai since the beginning of the boom of domestic VC industry related to domestic IPOs and the gap between Beijing and Shanghai has been growing (See Figure 7\&8). It can be also observed that Beijing and Shenzhen were leading in terms of VC activities interchangeably. Despite the leading role of Shenzhen in early years, Beijing has experienced faster growth in recent years and finally surpassed Shenzhen in 2012 in terms of both new listing firms and VC investments. Shanghai has also expanded its VC industry significantly, though not as much as Beijing and Shenzhen have done. The relatively low profile of Shanghai as a VC centre compared to Beijing and Shenzhen raises a question for further investigation. 


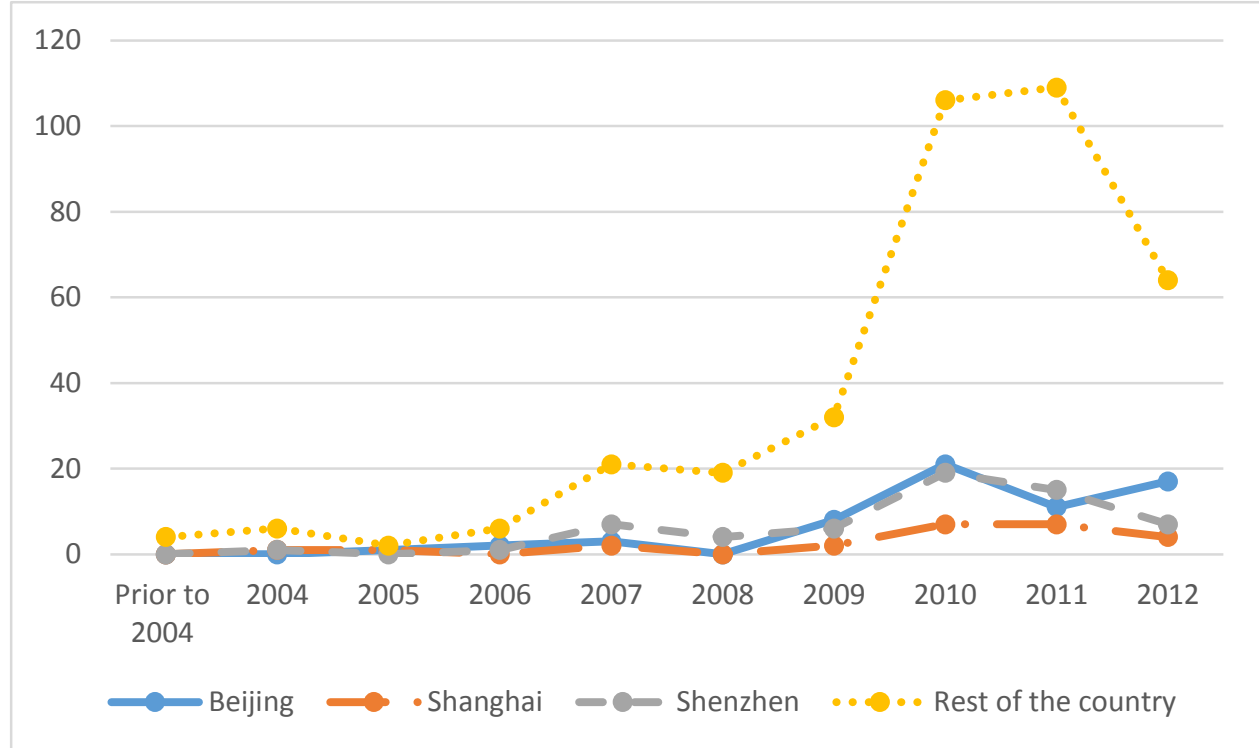

Figure 7 VC-backed new listings in Beijing, Shanghai and Shenzhen

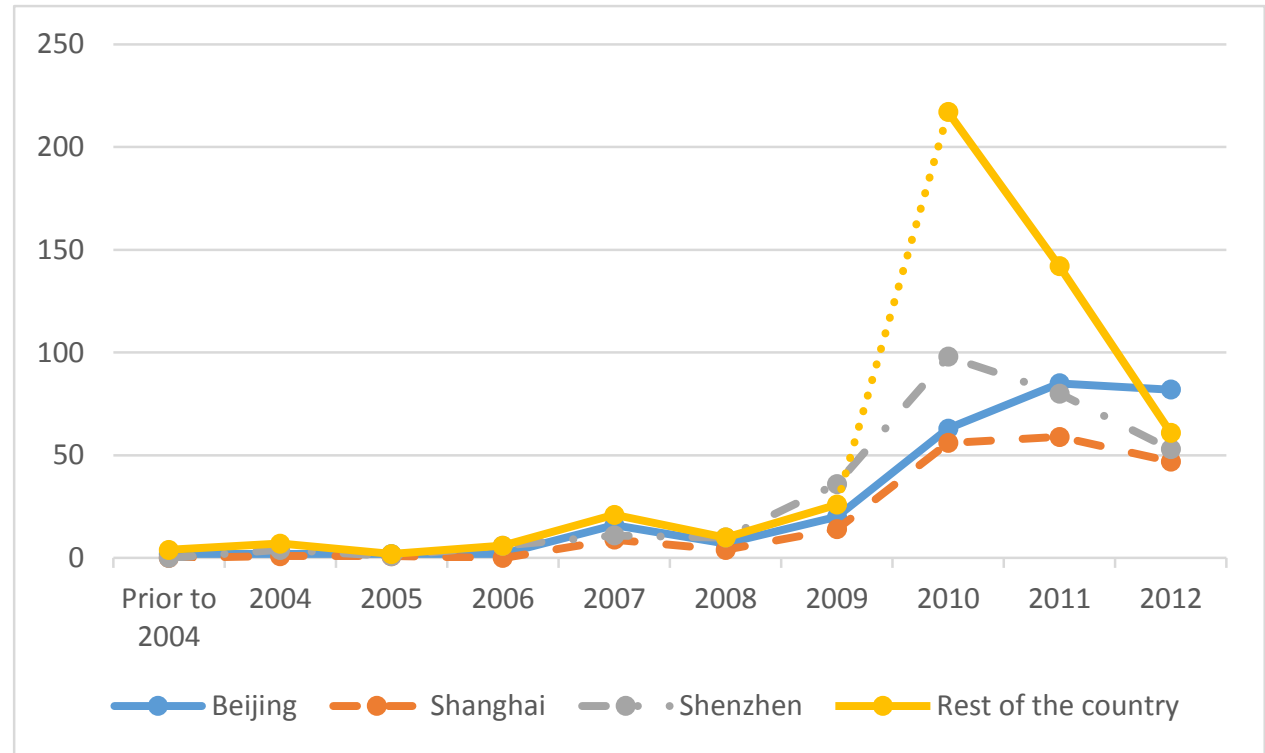

Figure 8 VC Investment made by VC firms located in Beijing, Shanghai and Shenzhen

\section{VC centres and the institutional context}

Beijing, Shenzhen and Shanghai stand out as VC centres not only because they are the most dynamic urban economies of the country or have accumulated sufficient experience in this industry brought by foreign VC firms, but also because these cities have held strategic positions largely due to the institutional context of China's economy and capital market.

As pointed out in previous studies, VC firms can play a critical role in helping portfolio companies go through the IPO applications (Wang, Anderson and Chi, 2012). Thus, VC firms that have better access to key organizations controlling the IPO process are more likely to succeed in attracting portfolio firms and divesting through an IPO (Gucbilmez 2014, Jiang et al. 2014, Kambil et al. 2006). Key organizations controlling the IPO process, in turn, are distributed 
unevenly and their geography is likely to influence the geography and networks of VC flows.

Given the strategic positions of Beijing, Shenzhen and Shanghai in China's capital market, VC firms from these three cities have certain advantages. After domestic IPOs became the major way for VC firms to exit from investment, Shenzhen and Shanghai, in which two domestic stock exchanges are located, could offer favorable conditions for successful VC investments. Shenzhen, in particular, has become extremely important as domestic VC-backed IPOs during this period were mostly made in SMEB and Chinext, both at the Shenzhen Stock Exchange. As the regulatory centre of the financial sector in China, Beijing is home for CSRC and other agencies. The fact that all IPO applications need to be approved by CSRC (Zhao 2013) has given Beijing significant advantage in developing the VC industry. Thus, Beijing, Shenzhen and Shanghai are the cities where organizations key to the IPO process are located (See Figure 9).
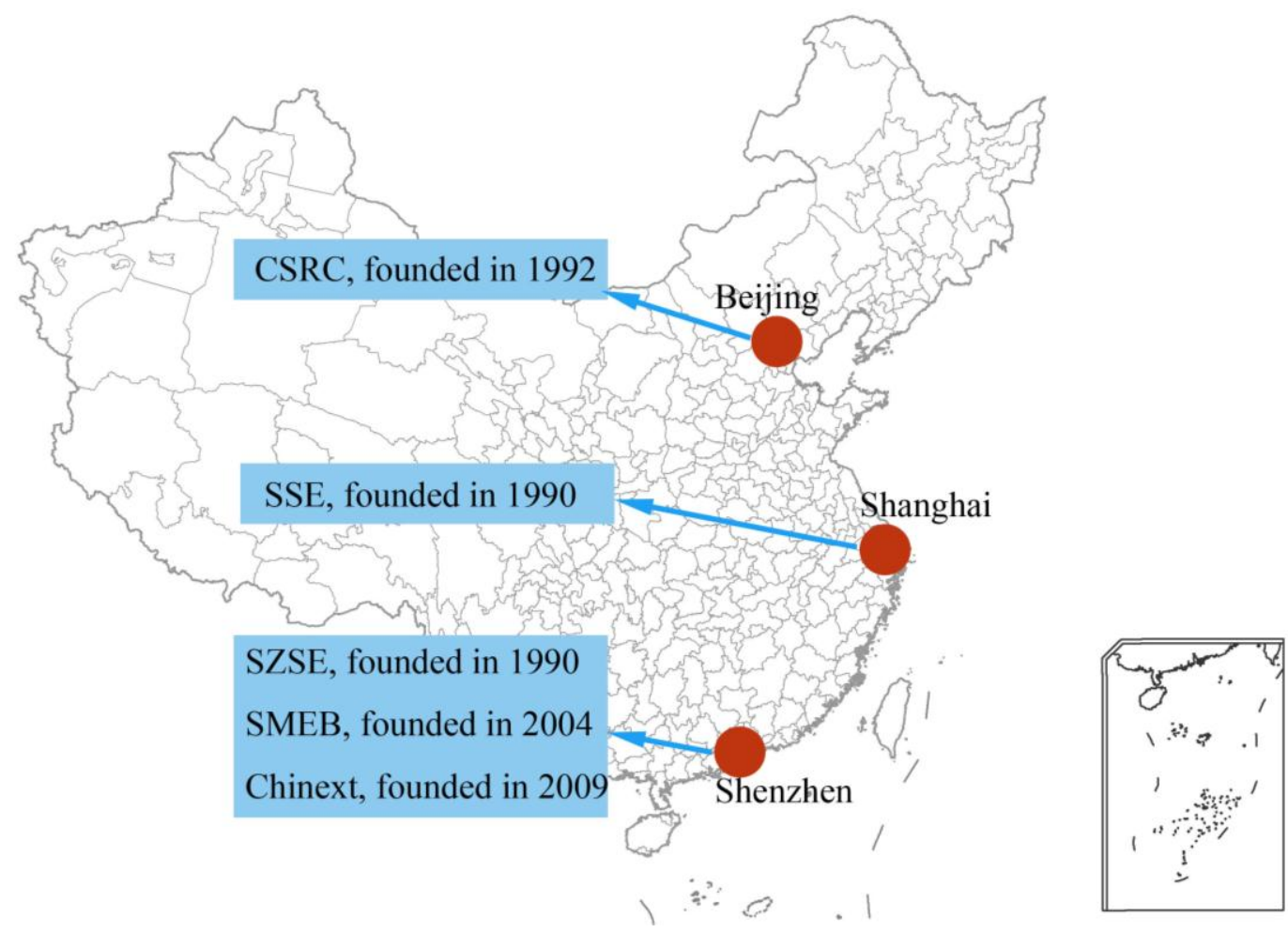

Figure 9 Geography of key institutions related to the IPO process

In fact, the reform of China's stock markets had fundamental consequences for Shenzhen and Shanghai as VC centres. In 2000, the central government decided to differentiate the function of the two domestic stock exchanges. From then on, SSE has become the main board for new listings of large firms, while Shenzhen Stock Exchange (SZSE) was planned to be home to Nasdaq-like boards. Regardless of the fact that the SMEB was not launched until 2004, the market has expected the Nasdaq-like board to be set up in Shenzhen for a while since the early 2000s and VC firms in Shenzhen have been the most prepared to invest in firms targeting domestic listings. Thus, Shenzhen became the hub of VC industry and the city's registered VC firms and their investments accounted for one-third of the national total in $2003^{8}$ (China Daily, 2004). As shown in Table 5,

8 http://www.china.org.cn/english/BAT/98542.htm 
the top two most active VC firms in our dataset are from Shenzhen and they were all established before 2003. The launch of Chinext has strengthened the importance of Shenzhen as a VC centre. Most VC-backed firms have been listed on SMEB and Chinext. Among all the listed firms backed by VC, 253 are listed on the SMEB, 205 on the Chinext, 56 on the SSE and only 2 on the main board of SZSE.

The government plays a key role in China's economy (Naughton 2011) and its capital market. The IPO approval system has made Beijing a leading node in China's VC industry. It has been documented that political ties are extremely important in IPO applications (Gucbilmez 2014, Jiang et al. 2014, Zhang 2014, Tan et al. 2013), and so the VC firms well connected with the government have more chances to exit from investment through IPO in a shorter period of time (Wang et al. 2013). State-owned VC firms have certain advantages. In our sample, more than $56 \%$ of all investments were made by state-owned VC firms. Among all 281 investments made by VC firms located in Beijing, over 52\% of them are made by the state-owned VC firms. Moreover, over $85 \%$ of the state-owned VC firms were controlled by centrally-directed state-owned companies. Similarly, among all 299 investments made by VC firms located in Shenzhen, 54\% are made by state-owned VC firms. Surprisingly, the figure of Shanghai is only $37 \%$.

As shown in Table 6, eleven out of the top 18 most active VC firms with no fewer than 10 investments are state-owned. The dominant role of state-owned VC firms has further strengthened Beijing's position in China's VC industry, as Beijing is home to many centrally controlled VC firms. VC firms from Beijing are more likely to have political connections to help portfolio companies get publicly listed. While Jiuding Capital, one of the most successful privately-owned VC firms located in Beijing may seem an exception, the two major founders of the firm were previously officials in CSRC and People's Bank of China before they started their business. The fact that Beijing surpassed Shenzhen as the leading city in VC activities in 2012 might indicate that the political centre has gained more influence over the capital market centre.

Table 6 The most active VC firms with at least 10 investments

\begin{tabular}{|l|r|l|l|l|}
\hline Firm & \#deals & Ownership & City & $\begin{array}{l}\text { Start } \\
\text { Year }\end{array}$ \\
\hline Shenzhen Capital Group & 56 & State-owned & Shenzhen & 2002 \\
\hline Fortune Capital & 33 & State-owned & Shenzhen & 2000 \\
\hline $\begin{array}{l}\text { China Science \& Merchants Investment } \\
\text { Management (CSC) Group }\end{array}$ & 32 & State-owned & Beijing & 2000 \\
\hline Govtor Capital & 24 & State-owned & Nanjing & 2005 \\
\hline Co-Win Venture Capital & 24 & Private & Shenzhen & 2000 \\
\hline Jiuding Capital & 23 & Private & Beijing & 2007 \\
\hline Sinowisdom Capital & 18 & Private & Hangzhou & 2002 \\
\hline Goldstone Investment & 18 & State-owned & Beijing & 2007 \\
\hline Green Pine Capital & 15 & State-owned & Shenzhen & 2007 \\
\hline GF Xinde Investment & 14 & State-owned & Guangzhou & 2008 \\
\hline
\end{tabular}

${ }^{9}$ China Science \& Merchants Investment Management (CSC) Group (Zhong Ke Zhao Shang) was initially established in Shenzhen as a state-owned VC firm and was privatized later. 


\begin{tabular}{|l|r|l|l|l|}
\hline CDF Capital & 13 & Private & Shenzhen & 2007 \\
\hline $\begin{array}{l}\text { Suzhou International Development } \\
\text { Venture Capital }\end{array}$ & 13 & State-owned & Suzhou & 2008 \\
\hline Guosen Investment & 13 & State-owned & Shenzhen & 2008 \\
\hline Haitong-Fortis Private Equity Fund & 12 & Joint-venture & Shanghai & 2004 \\
\hline NewMargin Ventures & 12 & State-owned & Shanghai & 1999 \\
\hline IDG Capital & 10 & Foreign & Beijing & 1992 \\
\hline Oriza Holdings & 10 & State-owned & Suzhou & 2001 \\
\hline
\end{tabular}

\section{Conclusion}

China's domestic VC industry started to boom due to the launch of two new stock market boards in Shenzhen in 2004 and 2009, as they give VC firms opportunity to exit from their investments through an IPO. With the success of VC firms involved in pre-IPO investments, the VC activities spread over the country quickly. Based on the data for all $\mathrm{VC}$ investments in firms that were ultimately listed on domestic stock exchanges, processed using conventional location analysis as well as city-network methodology, including the concept of city-dyads, we confirm the importance of three regions and three cities within China's VC landscape. At the regional level the Yangtze Delta Area is the leading one with Shanghai as the centre surrounded by a cluster of cities with significant VC presences. At the urban level Beijing and Shenzhen outperform Shanghai significantly. One important reason is that the key resources related to domestic IPOs are located in Beijing and Shenzhen. What is particularly surprising about Shanghai is that its VC firms are relatively weakly connected with the rest of the Yangtze Delta.

The spatial pattern of VC in China has more similarities with the geography of VC in the USA than the UK. In contrast to a unipolar London-centred VC industry in the UK, in China it is a multi-polar system, which is not surprising given the continental size of the Chinese economy and its multi-polar urban structure. The level of concentration, however, is high, with few regions and cities in the lead. Like in the USA, there are also significant flows of VC connecting distant regions. Just as New York-based VC firms invest heavily in Silicon Valley, Beijing VC firms invest in the Yangtze and Pearl Delta areas. And like in the USA and the UK, in China VC firms and $\mathrm{VC}$ invested firms concentrate in the most developed regions and cities, deepening existing income and wealth disparities. This research has applied a new strategy to construct urban linkages. The findings of the paper prove that city network and city-dyad analysis are quite useful in unpacking the flows of capital between cities and the position of cities in China's VC landscape.

Broad similarities between the spatial structure of VC in the USA and China notwithstanding, in our view the mix of factors that shapes the geography of VC differs considerably between the two countries. In the USA it seems to be driven by the geography of innovation and high-technology industry in the first place, as reflected by the undisputed dominance of Silicon Valley, and the geography of financial centres in the second (Florida, 2013). While San Francisco, Boston and 
New York are all leading US financial centres, the hierarchy of VC centres in the USA diverges significantly from that of financial centres, with San Jose, San Diego and Austin as medium-sized financial but top VC centres, with Chicago and Philadelphia as top financial but only medium-sized VC centres (Wójcik, 2011b). In China, geography of innovation does not appear to have an obvious upper hand over geography of financial centres in shaping the landscape of VC. While Beijing and Shenzhen are the leading high-technology centres in China, together with Shanghai they also represent the dominant financial centres. There is surely no equivalent of Silicon Valley in China. What in our view also distinguishes the US market is the level of financial integration, with major investment banks, key players in the IPO process, operating across national market and connecting financial centres with centres of VC. All big Wall Street investment banks, for example, maintain significant presence not only in Sillicon Valley but also other major VC hubs. While this requires further research, we would argue that the Chinese capital market is much less nationally integrated than that of the USA, particularly in terms of investment banking services.

What in our view distinguished the Chinese VC landscape centres the Chinese institutional and cultural context (Kambil et al. 2006, White et al. 2005, Zhang 2011, Ahlstrom et al. 2007, Bruton and Ahlstrom 2003, Humphery-Jenner and Suchard 2013, Pukthuanthong an d Walker 2007). In fact, domestic listing firms are more scattered than VC firms and man $\mathrm{y}$ of the listing firms are located in the economically less developed areas of the country. Given the composition of the VC-backed listing firms, the institutions influences are mor e important than technology capacity in shaping the spatial and network patterns of $\mathrm{VC}$ ac tivities related to domestic IPOs. As highlighted in previous studies, venture capital in Asi an economies have been thought to be different from that in western economies due to th e different regulatory environment (Bruton, Ahlstrom and Yeh 2004, Naqi and Hettihewa 2 007). In particular, the regulation of IPOs and the active involvement of state in capital $\mathrm{m}$ arkets and $\mathrm{VC}$ investments probably constitute the key institutional context to understandin $\mathrm{g}$ domestic VC activities in China. The ongoing interests of governments of different level $\mathrm{s}$ in providing funds for $\mathrm{VC}$ firms might continue to shape the geography of VC activities in the country (White et al. 2005, Naqi and Hettihewa 2007).

The future geography of domestic VC industry might be significantly influenced by national and local policy initiatives and institutional changes related to capital markets (Wójcik 2011). On the one hand, the establishment of National Equities Exchange and Quotations in 2012 in Beijing, which is more like a real NASDAQ board, may well strengthen the role of Beijing in China's VC industry. On the other hand, when a more transparent registration system replaces the IPO approval system dominated by CSRC and different levels of governments, the importance of Beijing as the regulatory centre for IPOs may decrease. In the meantime, Shanghai has been pushing to set up its own new board in order to develop high-tech industry ${ }^{10}$, a reflection of its ambition to close the gap with Beijing and Shenzhen.

10 http://www.chinadaily.com.cn/bizchina/2014-03/24/content_17372643.htm 


\section{References}

Ahlstrom, D., G. Bruton \& K. Yeh (2007) Venture capital in China: Past, present, and future. Asia Pacific Journal of Management, 24, 247-268.

Barry, C. B., C. J. Muscarella, J. W. Peavy \& M. R. Vetsuypens (1990) THE ROLE OF VENTURE CAPITAL IN THE CREATION OF PUBLIC COMPANIES - EVIDENCE FROM THE GOING-PUBLIC PROCESS. Journal of Financial Economics, 27, 447-471.

Batjargal, B. (2007) Internet entrepreneurship: Social capital, human capital, and performance of Internet ventures in China. Research Policy, 36, 605-618.

Bruton, G., D. Ahlstrom \& K. S. Yeh (2004) Understanding venture capital in East Asia: the impact of institutions on the industry today and tomorrow. Journal of World Business, 39, 72-88.

Bruton, G. D. \& D. Ahlstrom (2003) An institutional view of China's venture capital industry: Explaining the differences between China and the West. Journal of Business Venturing, 18, 233-259.

Chen, H., P. Gompers, A. Kovner \& J. Lerner (2010) Buy local? The geography of venture capital. Journal of Urban Economics, 67, 90-102.

Derudder, Taylor, Witlox \& Catalano (2003) Hierarchical Tendencies and Regional Patterns in the World City Network: A Global Urban Analysis of 234 Cities. Regional Studies, 37, 875-886.

Derudder, B., P. Taylor, Pengfei Ni, A. De Vos, M. Hoyler, H. Hanssens, D. Bassens, Jin Huang, F. Witlox, Wei Shen \& Xiaolan Yang (2010) Pathways of Change: Shifting Connectivities in the World City Network, 2000-08. Urban Studies, 47, 1861-1877.

Florida, R. \& D. F. Smith (1993) VENTURE CAPITAL FORMATION, INVESTMENT, AND REGIONAL INDUSTRIALIZATION. Annals of the Association of American Geographers, 83, 434-451.

Florida, R. L. \& M. Kenney (1988) VENTURE CAPITAL, HIGH TECHNOLOGY AND REGIONAL-DEVELOPMENT. Regional Studies, 22, 33-48.

Florida, R. (2013) America's leading metros for venture capital. http://www.citylab.com/work/2013/06/americas-top-metros-venture-capital/3284/. Accessed on 19 April 2016.

Fritsch, M. \& D. Schilder (2012) The Regional Supply of Venture Capital: Can Syndication Overcome Bottlenecks? Economic Geography, 88, 59-76.

Gompers, P. A. (1996) Grandstanding in the venture capital industry. Journal of Financial Economics, 42, 133-156.

Green, S. 2004. The Development of China's Stockmarket, 1984-2002: Equity Politics and Market Institutions. London: Routledge.

Gucbilmez, U. (2014) Why do some Chinese technology firms avoid ChiNext and go public in the US? International Review of Financial Analysis, 36, 179-194.

Gulati, R. \& M. C. Higgins (2003) Which ties matter when? The contingent effects of interorganizational partnerships on IPO success. Strategic Management Journal, 24, 127-144.

Hochberg, Y. V., A. Ljungqvist \& Y. Lu (2007) Whom you know matters: Venture capital networks and investment performance. Journal of Finance, 62, 251-301.

Humphery-Jenner, M. \& J.-A. Suchard (2013) Foreign VCs and venture success: Evidence from China. Journal of Corporate Finance, 21, 16-35.

Jiang, P., C. X. Cai, K. Keasey, M. Wright \& Q. Zhang (2014) The role of venture capitalists in small and medium-sized enterprise initial public offerings: Evidence from China. International Small 
Business Journal, 32, 619-643.

Kambil, A., V. W. T. Long \& C. Kwan (2006) The seven disciplines for venturing in China. Mit Sloan Management Review, 47, 85-+.

Lerner, J. 2010. Geography, Venture Capital, and Public Policy. In Policy Briefs. Harvard Kennedy School (Rappaport Institute for Greater Boston and Taubman Center for State and Local Government).

Lu, H., Y. Tan \& H. Huang (2013) Why do venture capital firms exist: An institution-based rent-seeking perspective and Chinese evidence. Asia Pacific Journal of Management, 30, 921-936.

Martin, R., C. Berndt, B. Klagge \& P. Sunley (2005) Spatial proximity effects and regional equity gaps in the venture capital market: evidence from Germany and the United Kingdom. Environment and Planning $A, 37,1207-1231$.

Martin, R., P. Sunley \& D. Turner (2002) Taking risks in regions: the geographical anatomy of Europe's emerging venture capital market. Journal of Economic Geography, 2, 121-150.

Mason, C. \& Y. Pierrakis (2013) Venture Capital, the Regions and Public Policy: The United Kingdom since the Post-2000 Technology Crash. Regional Studies, 47, 1156-1171.

Mason, C. M. \& R. T. Harrison (2002) The geography of venture capital investments in the UK. Transactions of the Institute of British Geographers, 27, 427-451.

Naqi, S. A. \& S. Hettihewa (2007) Venture capital or private equity? The Asian experience. Business Horizons, 50, 335-344.

Naughton, B. (2011) China's economic policy today: The new state activism. Eurasian Geography and Economics, 52, 313-329.

Pan, F. \& D. Brooker (2014) Going global? Examining the geography of Chinese firms' overseas listings on international stock exchanges. Geoforum, 52, 1-11.

Pukthuanthong, K. \& T. Walker (2007) Venture capital in China: a culture shock for Western investors. Management Decision, 45, 708 - 731.

Schwartz, D. \& R. Bar-El (2007) Venture investments in Israel - a regional perspective. European Planning Studies, 15, 623-644.

Segal, A. \& E. Thun (2001) Thinking globally, acting locally: local governments, industrial sectors, and development in China. Politics \& Society, 29, 557-588.

Sorenson, O. \& T. E. Stuart (2001) Syndication Networks and the Spatial Distribution of Venture Capital Investments. AMERICAN JOURNAL OF SOCIOLOGY, 106, 1546-1588.

Tan, Y., H. Huang \& H. T. Lu (2013) The Effect of Venture Capital Investment-Evidence from China's Small and Medium-Sized Enterprises Board. Journal of Small Business Management, 51, 138-157.

Taylor, P., B. Derudder, M. Hoyler, P. Ni \& F. Witlox (2014a) City-Dyad Analyses of China's Integration into the World City Network. Urban Studies, 51, 868-882.

Taylor, P. J. (2005) Leading world cities: empirical evaluations of urban nodes in multiple networks. Urban Studies, 42, 1593-1608.

Taylor, P. J. \& R. Aranya (2008) A Global 'Urban Roller Coaster'? Connectivity Changes in the World City Network, 2000-2004. Regional Studies, 42, 1-16.

Taylor, P. J., G. Catalano \& D. R. Walker (2002) Exploratory analysis of the world city network. Urban Studies, 39, 2377-2394.

Taylor, P. J., B. Derudder, J. Faulconbridge, M. Hoyler \& P. Ni (2014b) Advanced Producer Service Firms as Strategic Networks, Global Cities as Strategic Places. Economic Geography, 90, 267-291. 
Walter, C. \& F. Howie. 2003. Privatizing China: The stock markets and their role in corporate reform. Wiley.

Wang, Q., H. Anderson \& J. Chi (2013) Venture Capital Performance in China. http://ssrn.com/abstract=2357728 (last accessed November 24, 2015).

White, S., J. Gao \& W. Zhang (2005) Financing new ventures in China: System antecedents and institutionalization. Research Policy, 34, 894-913.

Wójcik, D. (2011a). The Global Stock Market: Issuers, investors and intermediaries in an uneven world. Oxford: Oxford University Press.

Wójcik, D. (2011b) Securitization and its footprint: the rise of the US securities industry centres 1998-2007. Journal of Economic Geography, 11:6, 925-947.

Zhang, J. (2008) China's Dynamic Industrial Sector: The Internet Industry. Eurasian Geography and Economics, 49, 549-568.

Zhang, J. (2011) The spatial dynamics of globalizing venture capital in China. Environment and Planning A, 43, 1562-1580.

Zhang, J. (2013) Related Variety, Global Connectivity and Institutional Embeddedness: Internet Development in Beijing and Shanghai Compared. Regional Studies, 47, 1065-1081.

Zhang, L. (2014) Corporate Governance of Chinese State-controlled Listed Companies: A Revisit Through the Lens of Venture Capital. European Business Organization Law Review, 15, 107-139.

Zhang, Z. \& Y. Li (2015) Why do ChiNext board firms accept private equity shortly before IPO: An Explanation from trade-off perspective. https://www.researchgate.net/publication/267248121_Why_do_ChiNext_board_firms_acce pt_private_equity_shortly_before_IPO_An_Explanation_from_trade-off_perspective (last accessed Novemver 11, 2015).

Zhao, S. X. B. (2013) Information Exchange, Headquarters Economy and Financial Centers Development: Shanghai, Beijing and Hong Kong. Journal of Contemporary China, 22, 1006-1027.

Zook, M. A. (2002) Grounded capital: venture financing and the geography of the Internet industry, 1994-2000. Journal of Economic Geography, 2, 151-177. 